\title{
酸素橋により連結されたニトラトニトロシルルテニウム 複核錯体の水溶液中での化学的挙動
}

\author{
石山稔雄，松村 隆 \\ 大阪府立放射線中央研究所 \\ 堺市新家町 704 \\ 1971年 6 月 1 日 受理
}

\begin{abstract}
酸素橋により連結されたニトラトニトロシルルテニウム複核錯体の硝酸ナトリウムを含む中性水 溶液中での化学的挙動を調べた。このよ5な複核錯体は有機溶媒抽出による核燃料再処理過程にお いてもつくられるであろうといわれており, 簡単のために以前から (Ru-O-Ru) nitrate と呼ばれ ている。実験の結果つぎのようなことが明らかとなった。(Ru-O-Ru) nitrate が分解すると一部 分は沈殿するが，他の一部分については $\mathrm{Ru}$ に配位している $\mathrm{NO}^{+}$が空気酸化されて $\mathrm{NO}_{2}^{-}$まは $\mathrm{NO}_{3}^{-}$に変わり,酸素橋が切断されて 1 分子の水が配位したルテニル錯体となる。その組成について は元素分析, 分子量, 赤外線吸収スペクトル执よびモル伝導度の測定から, $\left[\mathrm{RuO}_{2}\left(\mathrm{NO}_{2}\right)\left(\mathrm{NO}_{3}\right)_{2}-\right.$ $\mathrm{H}_{2} \mathrm{O}$ J゙で示される陰イオン錯体であることが明らかとなった。
\end{abstract}

\section{1. 緒言}

ルテニウムは核燃料再処理廃液中に多量含まれてお り, その除染はきわめて困難であるとされている。そ の理由はルテニウムの水溶液中での化学的挙動がきわ めて複雑であるからである。従来から報告されている 放射性廃水中のルテニウム化合物の化学的形態にはつ ぎの 4 つがあげられる1”。(1)RuNOニトラト錯体，(2) $\mathrm{RuNO}$ ニトロ錯体，(3)錯体を形成していないRuNO ${ }^{3+}$ イオン, (4) (Ru-O-Ru) nitrate 複核錯体。Fletcher ら2) は酸素橋により連結されたニトラトニトロシルル テニウム複核錯体は四塩化炭素中において四酸化ルテ ニウムと一酸化窒素とが反応することにより得られ, そしてまたこのような複核錯体は有機溶媒抽出による 核然料再処理過程で, $\mathrm{RuO}_{4}$ と $\mathrm{NO}$ との反応によって るつくられるであろらということを報告している。こ の複核錯体は簡単のために $(\mathrm{Ru}-\mathrm{O}-\mathrm{Ru})$ nitrate と呼 ばれており，その組成式および化学式はそれぞれ $\mathrm{Ru}_{2}$ $\mathrm{N}_{6} \mathrm{O}_{15}$ および $\left[\mathrm{RuO}_{2}(\mathrm{NO})_{2} \mathrm{NO}_{3}\right]_{2} \mathrm{O}$ で与えられてい る3)。この ( Ru-O-Ru) nitrateはきわめて不安定で, その水溶液は弱酸性を呈し, また強酸性溶液中では次 式のよらな反応により分解して, ニトロシルルテニウ ムイオン, 硝酸および亜硝酸となり, 酸素が発生する ことが Fletcher ら゙)により報告されている。

$\left[\mathrm{RuO}_{2}(\mathrm{NO})_{2} \mathrm{NO}_{3}\right]_{2} \mathrm{O}+\mathrm{H}_{2} \mathrm{O} \rightarrow 2 \mathrm{RuNO}^{3+}+x \mathrm{HNO}_{3}$ $+y \mathrm{HNO}_{2}+z \mathrm{O}_{2}$ 一般に硝酸々性の廃水を中和した場 合, 廃水中には多量の硝酸ナトリウムが含まれる。こ のように硝酸ナトリウムを多量含む中性水溶液中での (Ru-O-Ru) nitrate の分解生成物の 単離と確認はま
だなされていない。前報 ${ }^{4), 5) て ゙ は ~}{ }^{106} \mathrm{Ru}$ で標識化した ( $\mathrm{Ru}-\mathrm{O}-\mathrm{Ru})$ nitrate は中性水溶液中において Cl型陰 イオン交換体にきわめて効果的に吸着されることを報 告した。この場合には (Ru-O-Ru)nitrateが分解して 一種の陰イオン錯体が形成されているのではないかと 推測した。本報ではこのような硝酸ナトリウムを含む 中性水溶液中での ( $\mathrm{Ru}-\mathrm{O}-\mathrm{Ru})$ nitrate の化学的挙動 を明らかにするために，その分解生成物として 1 つの 新しいアコルテニル錯体を単離し，元素分析, 分子量, 赤外線吸収スペクトルおよびモル伝導度の測定により その化学的性質を調べた結果を報告する。

\section{2. 実験方法}

\section{$2 \cdot 1$ 試 薬}

三塩化ルテニウム, $\mathrm{RuCl}_{3} \cdot \mathrm{H}_{2} \mathrm{O}$ (三津和化学 $\mathrm{K} \mathrm{K}$ 製 特級試薬) はそのまま使用した。四塩化炭素は甲田 ${ }^{6)}$ が報告した方法に従って精製したものを使用した。市 販のメタノールについてはマグネシウム粉末とヨウ素 で十分乾燥した。また硝酸ナトリウムは和光純薬 $\mathrm{K} \mathrm{K}$ 製特級試薬をそのまま使用した。

\section{$2 \cdot 2 （ \mathrm{Ru}-\mathrm{O}-\mathrm{Ru})$ nitrate の水溶液中での分解生成} 物の単離方法ならびにその分析結果

四酸化ルテニウムの四塩化炭素溶液は Shilohら"に より報告された方法により調製した。(Ru-O-Ru)nitrate の橙褐色粉末は Fletcherら ${ }^{2)}$ が報告した方法に 従い合成した。この化合物は元素分析から Fletcher らにより報告されたものと同じく $\mathrm{Ru}_{2} \mathrm{~N}_{6} \mathrm{O}_{15}$ の組成を あつ化合物であることが確認された。このようにして 
調製した $1 \mathrm{~g}$ の（Ru-O-Ru）nitrate の粉末を約 100 $\mathrm{m} l$ の蒸留水に溶かし, 室温で数時間放置してから不 溶物を口別する。口液は弱酸性を呈する。この口液に あらかじめ炭酸ガスを除いた $0.1 \mathrm{~N}$ の水酸化ナトリウ ム標準溶液を滴下して $\mathrm{pH}=6.0$ 亿調整した。生じた灰 褐色の沈殿を口別し, 得られた中性口液に約 $2 \mathrm{~g}$ の硝 酸ナトリウムを加えて湯浴上で蒸発乾固する。得られ た淡赤褐色の残さに少量のメタノールを加えて $(\mathrm{Ru}-$ $\mathrm{O}-\mathrm{Ru}$ ) nitrate の分解生成物を抽出する。この操作を 数回綝り返して過㮃の硝酸ナトリウムを除き再結晶す る。赤褐色の結晶が得られた。このような $(\mathrm{Ru}-\mathrm{O}-$ $\mathrm{Ru}$ ) nitrate の分解生成物の単離方法を Table 1 亿と

Table 1 Schematic diagram of the isolation procedure of a decomposition product from $(\mathrm{Ru}-\mathrm{O}-\mathrm{Ru})$ nitrate aqueous solution

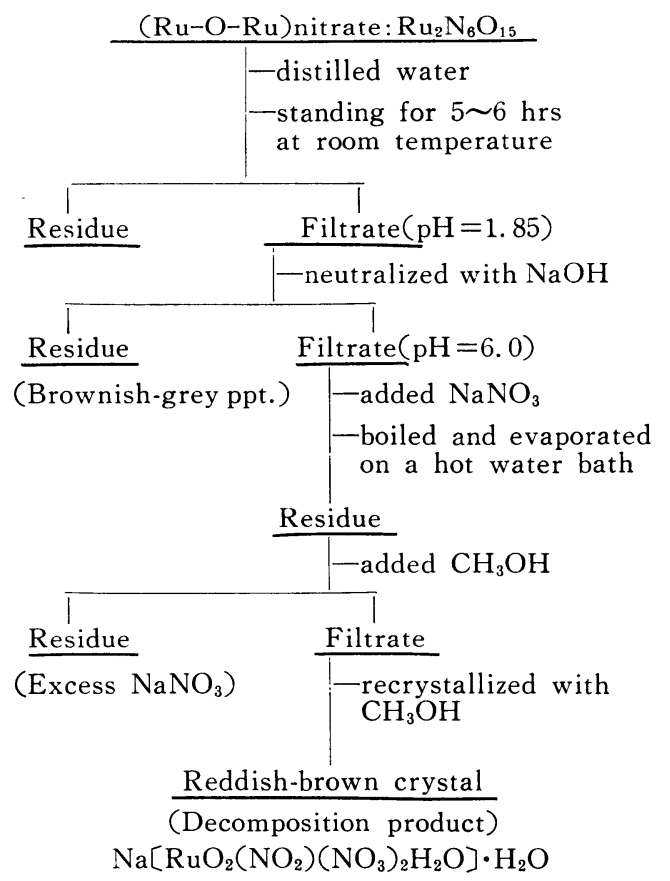

りまとめた。このようして単離された新化合物の収率

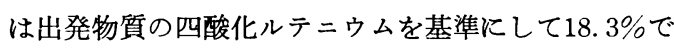
あった。この新化合物は四塩化炭素, ベンゼン, エー テルおよびジオキサンには溶けないが，水，メタノー ル,エタノール,アセトンおよび酢酸には可溶である。 この化合物中に含まれているルテニウムは向田ら ${ }^{8)}$ が 報告した方法により定量された。また結晶水について は前報9) と同様に示差熱分析によりその有無を確認 し，熱天秤による重量減少量からそれを定量した。分 子量については，まず新化合物を $110^{\circ} \mathrm{C} に て$ 約 24 時間
加熱後吸引乾燥して無水物を精製した。このような操 作を加えても化合物の構造は不変であることが赤外線 吸収スペクトルから確認された。このようにして得ら れた無水物をメタノールに溶かし, 柴山科学器械 $\mathrm{K} \mathrm{K}$ 製蒸気漫透圧計を用いて分子量を測定した。

実測値 : $\mathrm{Ru}, 27.45 ; \mathrm{H}, 1.14 ; \mathrm{N}, 11.73 ; \mathrm{H}_{2} \mathrm{O}, 4.73$ $\%$; 分子量 380 。 $\mathrm{Na}\left[\mathrm{RuO}_{2}\left(\mathrm{NO}_{2}\right)\left(\mathrm{NO}_{3}\right)_{2} \mathrm{H}_{2} \mathrm{O}\right] \cdot \mathrm{H}_{2} \mathrm{O}$ としての計算值: $\mathrm{Ru}, 27.90 ; \mathrm{H}, 1.10 ; \mathrm{N}, 11.60$; $\mathrm{H}_{2} \mathrm{O}, 4.97 \%$; 分子量, 362 。

\section{$2 \cdot 3$ 赤外線吸収スペクトル}

得られた新化合物の赤外線吸収スペクトルを日本分 光 $K K$ 製 IR-S型赤外線分光光度計を用い, $\mathrm{KBr}$ 錠剤 法により測定した。またこの化合物に含まれている配 位水を確認するため，前もって $110^{\circ} \mathrm{C} て ゙$ 約 24 時間加熱 した試料について測定を行なった。一方, $\mathrm{pH} \leqq 8.5$ の 微アルカリ性に調整した重水に試料を溶かし, 室温で 数日間放置して重水置換した試料についても同様に測 定を行なった。

\section{$2 \cdot 4$ モル伝導度}

モル层導度の測定には柳本製作所製MY-7 型電気伝 導度測定装置を用いた。測定試料を $25 \mathrm{~m} l$ の伝導度測 定用水に溶かし, 液温を $25^{\circ} \mathrm{C}$ 調整して $10^{-2} \sim 10^{-3}$ $\mathrm{mol} / l$ の濃度範囲で数回測定を行なった。

\section{3. 実験結果および考察}

\section{$3 \cdot 1$ 新化合物の化学組成}

元素分析の結果から (Ru-O-Ru) nitrate の中性水 溶液中での分解生成物について, $\mathrm{Ru}: \mathrm{H}: \mathrm{N}$ の比は 1 ：4：3であることがわかった。また分子量測定の結 果, この化合物は単核錯体であった。また熱分析の結果 から 1 分子の結晶水が含まれていることがわかった。

\section{$3 \cdot 2$ 赤外線吸収スペクトル}

得られた新化合物の赤外線吸収スペクトルをFig. I (Curve I) に示す。これによると 3440 と $1640 \mathrm{~cm}^{-1}$ に おいて配位水の伸縮振動および变角振動に由来する吸 収帯がそれぞれ認められた。また1525と1510および 1292 と $1265 \mathrm{~cm}^{-1}$ にみられる吸収帯の位置および形が $\left[\mathrm{Pd}\left(\mathrm{NO}_{3}\right)_{2} \text { bipy }\right]^{10), 11)}$ およびcis- $\mathrm{UO}_{2}\left(\mathrm{NO}_{3}\right)_{2} \cdot 3 \mathrm{H}_{2} \mathrm{O}$ 12),13) 飞打ける $\mathrm{NO}_{3}$ の伸縮振動に上る吸收帯のそれと 類似していることから，これら 4 つの吸収帯は Ruに 配位した $\mathrm{NO}_{3}$ の伸縮振動によるものと考兄られる。ま た1425，1395および $1335 \mathrm{~cm}^{-1}$ にみられる吸收帯はい 


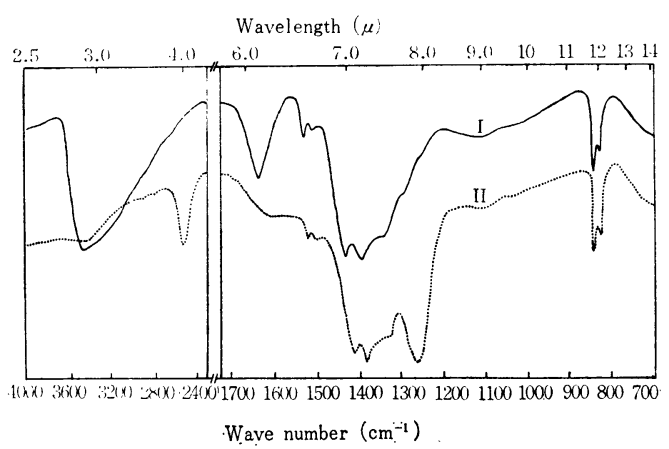

Fig. 1 Infrared absorption spectra.

Curve I: $\mathrm{Na}\left[\mathrm{RuO}_{2}\left(\mathrm{NO}_{2}\right)\left(\mathrm{NO}_{3}\right)_{2} \mathrm{H}_{2} \mathrm{O}\right]$,

Curve II: $\mathrm{Na}\left[\mathrm{RuO}_{2}\left(\mathrm{NO}_{2}\right)\left(\mathrm{NO}_{3}\right)_{2} \mathrm{D}_{2} \mathrm{O}\right]$

ずれも配位した $\mathrm{NO}_{2}$ の伸縮振動に由来するものであ り, $835 \mathrm{~cm}^{-1}$ にみられる吸収帯は $\mathrm{NO}_{2}$ の変角振動に由 来するものと考えられる。また $\mathrm{O}=\mathrm{Ru}=\mathrm{O}$ の伸縮振動 に由来する吸収が $845 \mathrm{~cm}^{-1}$ において認められた。この ような $=\mathrm{M}=\mathrm{O}$ にる吸収は $\mathrm{Cs}_{2}\left[\mathrm{OsO}_{2}(\mathrm{CN})_{4}\right]$ では $830 \mathrm{~cm}^{-1}$ に, $\mathrm{K}_{2}\left[\mathrm{OsO}_{2}(\mathrm{OH})_{4}\right]$ で $790 \mathrm{~cm}^{-1}$ においてそ れぞれ確認されている ${ }^{14)}$ 。また本研究において単離さ れた新化合物には RuNOに基づく吸収が認められて いない。一方, $\mathrm{Ru}_{2} \mathrm{~N}_{6} \mathrm{O}_{15}$ で表わされる（Ru-O-Ru） nitrate では, Fletcher ${ }^{15)}$ が報告しているように Ru NO に基づく吸収が $1976 \mathrm{~cm}^{-1}$ および $968 \mathrm{~cm}^{-1}$ におい て認められているが，Ruに配位した $\mathrm{NO}_{2}$ に基づく吸 収は認められていない。また $\mathrm{NO}_{3} に$ 基づく強い吸収が 1543および $1276 \mathrm{~cm}^{-1}$ において認められている。この 事実から元の複核錯体, $\left[\mathrm{RuO}_{2}(\mathrm{NO})_{2} \mathrm{NO}_{3}\right]_{2} \mathrm{O}$ におい て, Ruに配位している NO は中性水溶液中で錯体が 分解するさいに空気酸化されて $\mathrm{NO}_{2}$ または $\mathrm{NO}_{3}$ に変 わったものと考光られる。 Meyer ら 16),17) は[Ru (bipy) ${ }_{2}(\mathrm{NO}) \mathrm{Cl}^{2+} \stackrel{\mathrm{OH}^{-}}{\longrightarrow}\left[\mathrm{Ru}(\text { bipy })_{2}\left(\mathrm{NO}_{2}\right) \mathrm{Cl}\right]$ の反応 においても同様な現象がおこることを確認している。

重水で置換した化合物 (Fig. 1, Curve II)ではCurve I において観測されている 3440 および $1640 \mathrm{~cm}^{-1}$ の吸

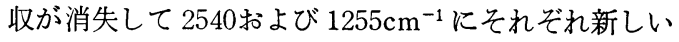
強い吸収が出現している。この事実から，本化合物の Ruには水が配位していることが確認された。

\section{$3 \cdot 3$ 新化合物のモル伝導度}

新化合物のモル伝導度を測定した結果, その平均值

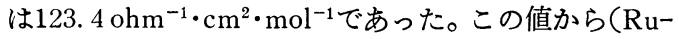
$\mathrm{O}-\mathrm{Ru}$ ) nitrate の中性水溶液中での分解により得られ た新化合物は $1 ： 1$ 型電解質であることが明らかとな
った。

\section{$3 \cdot 4 \mathrm{Ru}$ の酸化数}

四塩化炭素中において $\mathrm{RuO}_{4}$ と $\mathrm{NO}$ ガスとの反応に より形成される複核錯体がFletcherら ${ }^{3)}$ がさきに報告 しているように $\left[\mathrm{RuO}_{2}(\mathrm{NO})_{2} \mathrm{NO}_{3}\right]_{2} \mathrm{O} て ゙$ 表わされる構 造をとっているとすればこの複核錯体の分解反応によ りRuは 4価から 6価に酸化されたことになる。Brown ら ${ }^{1}$ はさきに RuNOニトラト錯体は空気の存在下で光 化学反応をおこして部分的に酸化され, $(\mathrm{Ru}-\mathrm{O}-\mathrm{Ru})$ VInitrate ができることを報告している。したがって $\left[\mathrm{Ru}^{\mathbb{}} \mathrm{O}_{2}(\mathrm{NO})_{2} \mathrm{NO}_{3}\right]_{2} \mathrm{O}$ が空気の存在する水溶液中に おいて分解する場合においても同様に，Ruが空気と 光による酸化作用で 4 価から 6 価に酸化されるのでは ないかと推測される。このように $\mathrm{RuO}_{4}$ と $\mathrm{NO}$ な゙スが 反応して形成される複核錯体, $\left[\mathrm{Ru}^{\mathbb{}} \mathrm{O}_{2}(\mathrm{NO})_{2} \mathrm{NO}_{3}\right]_{2} \mathrm{O}$ が $\mathrm{NO}_{3}^{-}$を含む中性水溶液中で分解して $\left[\mathrm{Ru}^{n} \mathrm{O}_{2}\left(\mathrm{NO}_{2}\right)\right.$ $\left(\mathrm{NO}_{3}\right)_{2} \mathrm{H}_{2} \mathrm{O}$ ]-で示されるルテニル錯陰イオンとなると いう事実はGriffith ${ }^{14)}$ が報告している $\mathrm{NO}_{2}^{-}$を含む中性 水溶液中での $\mathrm{OsO}_{4}$ と $\mathrm{NO}$ ガスとの反応, $6 \mathrm{NO}_{2}^{-}+2 \mathrm{O}_{5} \mathrm{O}_{4}$ $+4 \mathrm{NO}+\mathrm{H}_{2} \mathrm{O}=2\left[\mathrm{Os}^{n} \mathrm{O}_{2}\left(\mathrm{NO}_{3}\right)\left(\mathrm{NO}_{2}\right)_{3}\right]^{2-}+2 \mathrm{OH}^{-}+$ $\mathrm{N}_{2} \mathrm{O}$, に挴いてオスミル錯陰イオンができるという事 実と類似している。

以上の結果, 酸素橋により連結されたニトラトニト ロシルルテニウム複核錯体の硝酸ナトリウムを含む中 性水溶液中での化学的挙動は下記のようにまとめるこ とができると推測される。

$$
\begin{gathered}
{\left[\mathrm{Ru}^{\mathrm{I}} \mathrm{O}_{2}(\mathrm{NO})_{2} \mathrm{NO}_{3}\right]_{2} \mathrm{O} \frac{\mathrm{H}_{2} \mathrm{O}, \mathrm{NaNO}_{3}}{\mathrm{OH}^{-}(\mathrm{pH}=6.0)}} \\
2\left[\mathrm{Ru}^{\mathrm{I}} \mathrm{O}_{2}\left(\mathrm{NO}_{2}\right)\left(\mathrm{NO}_{3}\right)_{2} \mathrm{H}_{2} \mathrm{O}\right]^{-}
\end{gathered}
$$

本研究の一部は日本化学会第24年会, 錯体化学部門 においてロ頭発表した。

\section{文献}

1) P.G.M. Brown, J.M. Fletcher, C.J.Hardy, J. Kennedy, D. Scargill, A. G. Wain, and J.L. Woodhead: AEC-R, 17, 118 (1958)

2) J.M. Fletcher, I.L. Jenkins, F.M. Lever, F. S. Martin, A.R. Powell, and R. Todd : $J$. Inorg. Nucl. Chem., 1, 378 (1955)

3) F.S. Martin, J.M.Fletcher, P.G.M. Brown, and B.M. Gatehouse: J. Chem. Soc., 1959, 76

4) T.Ishiyama, T.Matsumura, and T.Mamu- 
ro: Ann. Rep. Rad. Ctr. Osaka, 6, 33(1965)

5）石山稔雄 : Radioisotopes, 17, 581 (1968)

6）甲田善生 : 名古屋工業技術試験所報告, 第15巻 第 5 号 p.155 (1966)

7) M.Shiloh, M. Givon, and K.S. Spieglar : $J$. Inorg. Nucl. Chem., 25, 103 (1963)

8）向田政男, 奥野久輝, 石森達二郎 : 日本化学雑 誌，第86巻，第 6 号， p.598 (1965)

9) T. Ishiyama : Ann. Rep. Rad. Ctr. Osaka, 8, 40 (1967)

10) B.M. Gatehouse : J. Inorg. Nucl. Chem., 8, 75 (1958)
11) B.M. Gatehouse, S.E. Livingstone, and R.S. Nyholm:J. Chem. Soc., 1957, 4222

12) L.H. Jone : J. Chem. Phys., 23, 2105 (1955)

13) B. M. Gatehouse, and A. E. Comyns : $J$. Chem. Soc., 1958, 3965

14) W.P.Griffith: J. Chem. Soc., 1962, 3248

15) J.M. Fletcher: J. Inorg. Nucl. Chem., 8, 277 (1958)

16) T.J. Meyer, J.B. Godwin, and N. Winterton: J. Chem. Soc. Chem. Comm., 14, 872(1970)

17) J.B. Godwin, and T.J. Meyer:Inorg. Chem., 10, 471 (1971)

\title{
Abstract
}

\section{The Chemical Behavior of Binuclear Oxygen-Bridged Nitrato- nitrosylruthenium Complex in an Aqueous Environment}

\author{
Toshio IsHIYAMA and Takashi MATSUMURA
}

Radiation Center of Osaka Prefecture, Shinke-cho, Sakai, Osaka

\begin{abstract}
The chemical behavior of binuclear oxygen-bridged nitratonitrosylruthenium complex was studied in neutral aqueous solution containing sodium nitrate. This binuclear complex has been referred to for convenience as ( $\mathrm{Ru}-\mathrm{O}-\mathrm{Ru})$ nitrate, and is formed in reactor fuel-reprocessing through solvent extraction. Following facts have been found. (1) Nitrosyl groups of the original binuclear complex change to nitro or nitrato group by air-oxidation.

(2) A charge-negative mononuclear aquo-ruthenyl complex with nitro and nitrato groups is formed, presumably due to the decomposition and air-oxidation of $(\mathrm{Ru}-\mathrm{O}-\mathrm{Ru})$ nitrate.
\end{abstract}

(Received June 1, 1971) 